Date:

Investigator initials:

\title{
Feasibility questionnaire
}

Instructions for administrator: show devices to participant throughout the questionnaire to remind them what each device is when you ask about it.

\section{Part A - consumer device}

Consumer device worn on this day:

$\square$ FitBit Charge HR

Garmin Vivosmart

1. How comfortable was it for you to wear the wrist-worn device during 1 day? Please choose the best answer.

\begin{tabular}{|c|c|c|c|c|}
\hline $\begin{array}{c}\text { Not very } \\
\text { comfortable }\end{array}$ & $\begin{array}{c}\text { Not } \\
\text { comfortabl } \\
\mathrm{e}\end{array}$ & Neutral & $\begin{array}{c}\text { Somewhat } \\
\text { comfortabl } \\
\mathrm{e}\end{array}$ & $\begin{array}{c}\text { Very } \\
\text { comfortabl } \\
\mathrm{e}\end{array}$ \\
\hline$\square$ & $\square$ & $\square$ & $\square$ & $\square$ \\
\hline
\end{tabular}

2. Did you have any problems wearing the devices?
$\square$ No
Y Yes

If Yes, please explain your answer:

3. These kinds of devices are usually used to measure physical activity over several days. How likely would you be to participate in a study where you had to wear the device every day for 1 week?

\begin{tabular}{|c|c|c|c|c|}
\hline $\begin{array}{c}\text { Very } \\
\text { unlikely }\end{array}$ & Unlikely & Maybe & Likely & $\begin{array}{c}\text { Very } \\
\text { likely }\end{array}$ \\
\hline$\square$ & $\square$ & $\square$ & $\square$ & $\square$ \\
\hline
\end{tabular}

4. Do you think you would have any problems or discomforts with wearing the device every day for a week?

Please choose the best answer.

\begin{tabular}{|c|c|c|c|c|}
\hline $\begin{array}{c}\text { Very } \\
\text { unlikely }\end{array}$ & Unlikely & Maybe & Likely & $\begin{array}{c}\text { Very } \\
\text { likely }\end{array}$ \\
\hline$\square$ & $\square$ & $\square$ & $\square$ & $\square$ \\
\hline
\end{tabular}

If you think there might be any problems or discomforts with wearing the devices on the daily basis, please explain your answer: 
Date:

Investigator initials:

5. Do you think you would have any problems or discomforts sleeping while wearing the device? Please choose the best answer.

\begin{tabular}{|c|c|c|c|c|}
\hline $\begin{array}{c}\text { Very } \\
\text { unlikely }\end{array}$ & Unlikely & Maybe & Likely & $\begin{array}{c}\text { Very } \\
\text { likely }\end{array}$ \\
\hline$\square$ & $\square$ & $\square$ & $\square$ & $\square$ \\
\hline
\end{tabular}

If you think there might be any problems or discomforts with sleeping while wearing the device, please explain your answer:

6. How confident are you that you would be able to put on and take off the wrist-worn device on your own if you were given the device to wear at home?

$0=$ not confident at all; $10=$ extremely confident

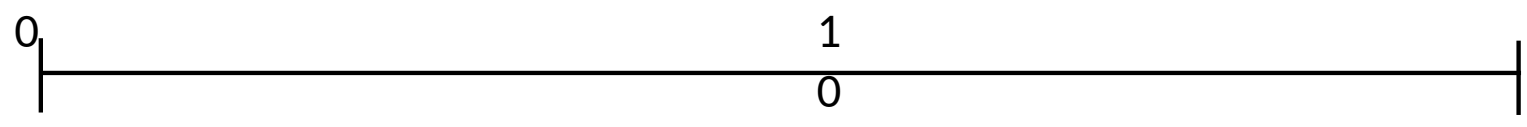

\section{$\underline{\text { Part B }}$}

\section{Complete on last day only.}

7. How comfortable was it for you to wear the chest strap and accelerometer during 1 day? Please choose the best answer.

\begin{tabular}{|l|c|c|c|c|c|}
\hline & $\begin{array}{c}\text { Not very } \\
\text { comfortable }\end{array}$ & $\begin{array}{c}\text { Not } \\
\text { comfortabl } \\
\mathrm{e}\end{array}$ & Neutral & $\begin{array}{c}\text { Somewhat } \\
\text { comfortabl } \\
\mathrm{e}\end{array}$ & $\begin{array}{c}\text { Very } \\
\text { comfortabl } \\
\mathrm{e}\end{array}$ \\
\hline Chest strap for 1 day & $\square$ & $\square$ & $\square$ & $\square$ & $\square$ \\
\hline $\begin{array}{l}\text { Accelerometer worn at the } \\
\text { ankle for 1 day }\end{array}$ & $\square$ & $\square$ & $\square$ & $\square$ & $\square$ \\
\hline
\end{tabular}

8. Did you have any problems wearing the devices?
$\square$ No
$\square$ Yes

If Yes, please explain your answer: 
Date:

Investigator initials:

9. These kinds of devices are usually used to measure physical activity over several days. How likely would you be to participate in a study where you had to wear the:

\begin{tabular}{|l|c|c|c|c|c|}
\hline & $\begin{array}{c}\text { Very } \\
\text { unlikely }\end{array}$ & Unlikely & Maybe & Likely & $\begin{array}{c}\text { Very } \\
\text { likely }\end{array}$ \\
\hline $\begin{array}{l}\text { Chest strap every day for } \\
1 \text { week? }\end{array}$ & $\square$ & $\square$ & $\square$ & $\square$ & $\square$ \\
\hline $\begin{array}{l}\text { Accelerometer at the } \\
\text { ankle every day for 1 } \\
\text { week? }\end{array}$ & $\square$ & $\square$ & $\square$ & $\square$ & $\square$ \\
\hline
\end{tabular}

10. Do you think you would have any problems or discomforts with wearing devices every day for a week?

Please choose the best answer.

\begin{tabular}{|l|c|c|c|c|c|}
\hline & $\begin{array}{c}\text { Very } \\
\text { unlikely }\end{array}$ & Unlikely & Maybe & Likely & $\begin{array}{c}\text { Very } \\
\text { likely }\end{array}$ \\
\hline $\begin{array}{l}\text { Chest strap every day for } \\
1 \text { week? }\end{array}$ & $\square$ & $\square$ & $\square$ & $\square$ & $\square$ \\
\hline $\begin{array}{l}\text { Accelerometer at the } \\
\text { ankle every day for } 1 \\
\text { week? }\end{array}$ & $\square$ & $\square$ & $\square$ & $\square$ & $\square$ \\
\hline
\end{tabular}

If you think there might be any problems or discomforts with wearing the devices on the daily basis, please explain your answer:

11. How confident are you that you would be able to put on and take off the chest strap on your own if you were given the device to wear at home?

$0=$ not confident at all; $10=$ extremely confident

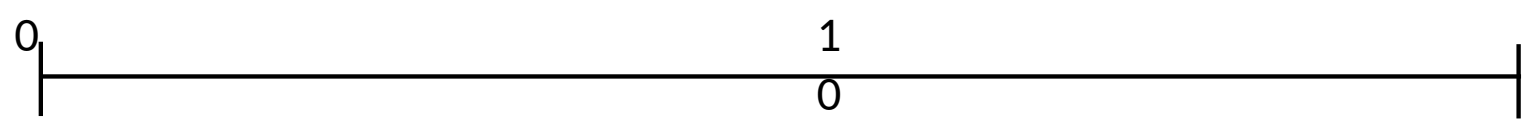

12. How confident are you that you would be able to put on and take off the accelerometer on your own if you were given the device to wear at home?

$0=$ not confident at all; $10=$ extremely confident

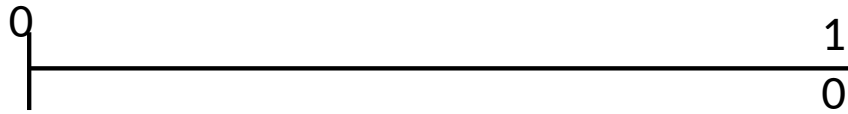

